P-ISSN: 2615-1723

E-ISSN: 2615-1766

April 2020
Jurnal Riset Pendidikan Dasar

03 (1), (2020) 77-86

Submitted: Maret, Accepted: Maret, Published: April

\title{
IMPLEMENTASI PROGRAM PENDIDIKAN KARAKTER DI SD KANISIUS GENDONGAN SALATIGA
}

\author{
Betles Natalini ${ }^{1}$, Agustina Tyas Asri Hardini ${ }^{2}$ \\ 1,2 Program Studi Pendididkan Guru Sekolah Dasar, Fakultas Keguruan dan Ilmu Pendidikan, \\ Universitas Kristen Satya Wacana Salatiga, Indonesia \\ Korespondensi. Email: 292016025@student.uksw.edu
}

\begin{abstract}
Abstrak
Penelitian ini bertujuan untuk: 1) mengevaluasi pelaksanaan program pendidikan karakter di SD Kanisius Gendongan Salatiga, 2) mendeskripsikan faktor yang mempengaruhi pelaksanaan program pendidikan karakter di SD Kanisius Gendongan Salatiga, 3) mendeskripsikan dampak program pendidikan karakter di SD Kanisius Gendongan Salatiga. Penelitian ini menggunakan pendekatan kualitatif dengan jenis penelitian evaluatif model goal free evaluation. Subyek penelitian ini meliputi 1 kepala sekolah, 2 guru, 3 orang tua serta 4 siswa SD Kanisius Gendongan Salatiga. Penelitian ini menggunakan beberapa teknik pengumpulan data, yaitu wawancara, observasi dan studi dokumen. Teknik analisis data yang digunakan dalam penelitian ini adalah teknis analisis data kualitatif model Miles dan Huberman yang meliputi : 1) pengumpulan data, 2) reduksi data, 3) penyajian data, 4) kesimpulan. Uji validitas dan reliabilitas yang dilakukan dalam penelitian ini meliputi: 1) uji krediabilitas, 2) uji depenability, 3) uji konfirmability, 4) uji transferability. Hasil penelitan menunjukkan SD Kanisius Gendongan Salatiga dalam implementasi program pendidikan karakter mengembangkan beberapa strategi seperti adanya sosialisasi, pengembangan pendidikan karakter dalam kegiatan sekolah, kegiatan pembelajaran, kegiatan ekstrakurikuler dan budaya sekolah. Implementasi program pendidikan karakter didukung oleh beberapa faktor seperti keadaan lingkungan belajar, lingkungan sosial, dan pola asuh orang tua. Namun tanggapan dan konsep diri dari sebagian peserta didik SD Kanisius Gendongan Salatiga masih memerlukan pembiasaan untuk menanamkan setiap nilai-nilai karakter yang baik. Program pendidikan karakter sangat baik dan penting untuk terus diimplementasikan dan dikembangkan karena berdampak positif bagi pembentukkan karakter peserta didik dan hasil dari nilai akademik peserta didik.
\end{abstract}

Kata kunci: pendidikan karakter, evaluasi program, goal free evaluation

\section{THE IMPLEMENTATION OF CHARACTER EDUCATION PROGRAM IN KANISIUS GENDONGAN SALATIGA}

\begin{abstract}
This research aims to: 1) evaluate the implementation of character education programs in SD Kanisius Gendongan Salatiga, 2) describe the factors that influence the implementation of character education programs in SD Kanisius Gendongan Salatiga, 3) describe the impact of character education programs in SD Kanisius Gendongan Salatiga. This study uses a qualitative approach to the type of evaluative research model goal free evaluation. The subjects of this study include 1 school principal, 2 teachers, 3 parents and 4 students from SD Kanisius Gendongan Salatiga. This study uses several data collection techniques, i.e. interviews, observation and document study. The data analysis technique used in this study is the qualitative data analysis technique of Miles and Huberman's model which includes: 1) data collection, 2) data reduction, 3) data presentation, 4) conclusion. Validity and reliability tests conducted in this study include: 1) credibility test, 2) depenability test, 3) confirmability test, 4) transferability test. Research result showed that SD Kanisius Gendongan Salatiga in implementing the character education program developed several strategies such as the existence of socialization, character education development in school activities, learning activities, extracurricular activities and school culture. The implementation of character education programs is supported by several factors such as the state of the learning environment, social environment, and parenting. However, the responses and self-concepts of some SD Kanisius Gendongan Salatiga students still need to be accustomed to instilling any good character values. The character education program is very good and it is important to continue to be implemented and developed because it has a positive impact on the formation of students 'character and the results of students' academic values.
\end{abstract}

Keywords: character education, evaluation program, goal free evaluation

$$
\text { Copyright } \text { C2020, JRPD, ISSN } 2615 \text { - } 1723 \text { (Print), ISSN } 2615 \text { - } 1766 \text { (Online) }
$$




\section{Jurnal Riset Pendidikan Dasar, 03 (1), April 2020 (77-86)}

Betles Natalini, Agustina Tyas Asri Hardini

\section{PENDAHULUAN}

Pendidikan karakter merupakan salah satu kunci keberhasilan pendidikan di Indonesia. Perhatian pemerintah terhadap pendidikan karakter bukanlah suatu hal yang baru, melainkan menempatkan pendidikan pada proporsi yang sesungguhnya, sebab ke depan bangsa Indonesia akan dipegang oleh generasi yang kini masih berada di jenjang pendidikan. Pada abad 21 ini terdapat perubahan positif yang terjadi di Indonesia, salah satunya adalah berkembangnya IPTEK di Indonesia, namun di sisi lain juga berdampak negatif, salah satunya yaitu munculnya degradasi moral. Degradasi moral merupakan penurunan sikap atau perilaku positif (Jahroh \& Sutarna, 2016). Implementasi pendidikan karakter yang tepat dalam kegiatan pembelajaran di sekolah dasar diharapkan mampu mengatasi masalah degradasi moral.

Sekolah memegang peran penting dalam pendidikan karakter, di samping keluarga dan lingkungan tempat tinggal. Terlebih pada jenjang pendidikan sekolah dasar, sekolah dasar merupakan tempat peserta didik pada tahap belajar melalui mengamati, menirukan dan mulai belajar menyelesaikan masalahnya sendiri. Hal ini membuat kepala sekolah dan guru SD harus mampu memberi perhatian yang lebih terhadap pendidikan karakter siswanya. Guru sebagai salah satu faktor pendukung terlaksananya pendidikan karakter diharapkan tidak hanya mampu membuka pikiran siswa dengan pengetahuanpengetahuan baru, namun juga harus mampu memupuk nilai-nilai dalam upaya membangun karakter yang positif bagi siswa. Pemerintah turut mendukung adanya pendidikan karakter di Indonesia, hal ini terbukti dengan adanya Perpres No.87 Tahun 2017 yang mengatur tentang penguatan pendidikan karakter di Indonesia.

Penelitian yang berkaitan dengan evaluasi program pendidikan karater dilakukan oleh Darmayanti dan Wibowo (2014) di beberapa sekolah dasar di Kabupaten Kulon Progo yang mendapat hasil bahwa program pendidikan karakter sudah terlaksana dilihat dari kurikulum sekolah yang sudah terintegrasi dengan pendidikan karakter. Hanya kurang maksimal dikarenakan kurangnya guru yang memiliki pengetahuan dan ketrampilan dalam mengimplementasikan pendidikan karakter dan kurangnya dukungan dari pemerintah dalam sosialisasi. Kendala lain yang dihadapi sekolah adalah belum adanya dokumentasi penilian sikap siswa. Penelitian lain tentang evaluasi pendidikan karakter dilakukan oleh Syaikhudin (2014) di Sekolah Dasar Ma'aruf Ponorogo, mendapat hasil dalam pelaksanaan program pendidikan karakter diawali dengan sosialisasi yang melibatkan komite sekolah, guru karyawan serta wali murid, secara umum pelaksanaan pendidikan karakter di SD Ma'aruf Ponorogo sudah berjalan dengan baik. SD Ma'aruf Ponorogo menanamkan 18 (delapan belas) nilai pendidikan karakter sesuai dengan yang dicanangkan oleh pemerintah.

Taunu dan Iriani (2019) dalam penelitian evaluasi program penguatan pendidikan di daerah Waingapu mendapat hasil bahwa implementasi program penguatan pendidikan karakter ini dimulai dari tahap perencanaan, pelaksanaan dan evaluasi. Pelaksanaan pendidikan karakter berdampak positif. Hanya saja terdapat beberapa faktor yang menghambat jalannya program ini, seperti kurangnya tenaga pendidik yang profesional dan akses informasi yang terbatas dan sikap mentalisasi peserta didik itu sendiri. Sofanudin (2015) melalui penelitian evaluatif di Tegal mendapat hasil bahwa strategi penanaman nilai-nilai karakter melalui mata pelajaran agama Islam dilakukan melalui kebijakan sekolah dan sistem sekolah. Terlaksananya program pendidikan karakter didukung adanya guru yang kompeten, sarana dan prasarana, serta kualifikasi peserta didik, dan adanya pembiasaan di sekolah. Adanya penanaman nilai karakter bangsa melalui Pendidikan Agama Islam berdampak positif seperti adanya peserta didik yang kompeten dan memiliki karakter yang baik.

Penelitian evaluasi program pendidikan karakter juga dilakukan Jaelani dan Asvio (2019) di SDN 22 Pulau Rimau. Program pendidikan 


\section{Jurnal Riset Pendidikan Dasar, 03 (1), April 2020 (77-86)}

Betles Natalini, Agustina Tyas Asri Hardini

karakter di SD tersebut dinilai baik dari adanya pengintegrasian kurikulum dengan pendidikan karakter. Kurang maksimalnya pelaksanaan program pendidikan karakter dilihat dari kurangnya kesiapan sekolah untuk memanfaatkan sarana dan prasarana sekolah. Sebagian besar dari tenaga pendidik juga belum memiliki pemahaman tentang pentingnya pendidikan karakter bagi peserta didik. Sosialisasi program pendidikan karakter diadakan oleh Dinas Pendidikan Kecamatan Rimau juga dirasa oleh sekolah kurang maksimal. Syamsani (2019) juga melakukan penelitian evaluasi program penguatan pendidikan karakter SDN No.39 Centre Palleko Kecamatan Polongbangkeng, Kecamatan Polongbakeng Utara, Kabupaten Takalar mendapat hasil bahwa keseluruhan dari pelaksanaan program pendidikan karakter yang dimulai dari tahap perencanaan, pelaksanaan dan hasil sudah baik. Terbukti dari perubahan sikap peserta didik yang sesuai dengan nilai-nilai pendidikan karakter.

Hasil penelitian yang ada menunjukkan bahwa program pendidikan karakter sudah dapat diterapkan di beberapa sekolah. Program pendidikan karakter berkaitan dengan beberapa faktor yang akan mempengaruhi keterlaksanaan program tersebut. Faktor pendukung keterlaksanaan program pendidikan karakter diantaranya adalah adanya kurikulum sekolah dan kegiatan belajar yang diintegrasikan dengan pendidikan karakter. Faktor penghambat keterlaksananya pendidikan karakter, seperti kurang tersedianya tenaga pendidik yang profesional dan berkarakter, akses informasi dan sikap mentalisasi peserta didik itu sendiri. Program pendidikan karakter yang sudah terlaksana di beberapa sekolah berdampak baik bagi peserta didik itu sendiri dan lingkungan sosialnya.

Program pendidikan karakter di SD perlu dievaluasi untuk mengukur keterlaksanaan program pendidikan karakter dan upaya tindak lanjut untuk perbaikan program. Evaluasi program merupakan implementasi dari suatu kebijakan, berlangsung dalam proses yang berkesinambungan dan terjadi pada sekelempok orang Arikunto \& Jabar (2004). Terdapat beberapa model untuk mengevaluasi suatu program, salah satunya adalah model Goal Free Evaluation yang digunakan oleh peneliti untuk mengevaluasi program pendidikan karakter. Model Goal Free Evaluation adalah model adalah model yang dikemukakan oleh Michael Scriven. Wirawan (2013) menyatakan bahwa evaluasi merupakan evaluasi tentang pengaruh dari program yang dilaksanakan.

Berdasarkan latar belakang yang telah digambarkan diatas, peneliti tertarik untuk melakukan penelitian evaluatif dengan model Goal Free Evaluation. Peneliti memilih model Goal Free Evaluation dikarenakan dalam model tersebut peneliti tidak berfokus pada tujuan utama diadakannya program pendidikan karakter, namun peneliti lebih berfokus pada pengaruh atau dampak yang sebenarnya terjadi dalam pelaksanaan program pendidikan karakter di SD Kanisus Gendongan Salatiga. Sehingga melalui penelitian Goal Free Evaluation ini mendapat hasil evaluasi dari pelaksanaan program, deskripsi faktor pengaruh program dan menentukan penting atau tidaknya program pendidikan karakter dilihat dari dampak yang sebenarnya terjadi. Peneliti memilih SD Kanisius Gendongan karena SD tersebut merupakan salah satu SD yang ada di Salatiga yang sudah melaksanakan program pendidikan karakter. Hal ini tergambar jelas dalam visi dari SD Kanisius Gendongan Salatiga, yaitu Unggul dalam pelayanan dan berkarakter atas dasar iman dan kasih menuju sekolah berkualitas. Adapun misi untuk mencapai visi yang ditanamkan SD Kanisius Gendongan Salatiga yaitu : 1) meningkatkan kecerdasan melalui proses pembelajaran yang aktif, kreatif, inovatif dan menyenangkan; 2) menumbuhkan budi pekerti luhur berdasarkan semangat kasih; 3) menanamkan sikap didiplin melalui pembiasaan hidup tertib dan bertanggung jawab; 4) menanamkan kejujuran melalui pembiasaan komitmen, dapat dipercaya dan diandalkan; 5) menanamkan keberanian melalui pembiasaan kritis, reflektif dan aksi. Selain itu SD Kanisius 


\section{Jurnal Riset Pendidikan Dasar, 03 (1), April 2020 (77-86)}

Betles Natalini, Agustina Tyas Asri Hardini

Gendongan Salatiga juga menanamkan nilai-nilai Kanisius diantaranya nilai kasih, berani, jujur, disiplin, gembira.

\section{METODE PENELITIAN}

Penelitian ini menggunakan pendekatan kualitatif dengan jenis penelitian evaluatif model goal free evaluation. Pendekatan kualitatif merupakan penelitian yang digunakan untuk meneliti pada kondisi obyek yang alamiah, dimana peneliti sebagai instrumen kunci, teknik pengumpulan data dilakukan secara triangulasi , analisis data bersifat induktif, dan hasil lebih menekankan makna daripada generalisasi (Sugiyono, 2017:9). Model evaluasi yang peneliti hendak lakukan adalah goal free evaluation, yaitu evaluasi tentang pengaruh dari program yang dilaksanakan (Wirawan, 2013:84).

Subyek penelitian ini meliputi kepala sekolah, 2 guru kelas, 3 orang tua siswa serta 4 siswa SD Kanisius Gendongan Salatiga. Penelitian ini akan dilakukan di Jln. Dr. Muwardi No. 4, Gendongan, Kec. Tingkir, Kota Salatiga, Jawa Tengah. Peneliti memilih subyek penelitian tersebut dikarenakan subyek tersebut berperan dalam terlaksananya program pendidikan karakter di SD Kanisius Gendongan Salatiga. Penelitian ini dilakukan pada bulan November 2019 sampai pada bulan Febuari 2020.

Penelitian ini menggunakan beberapa teknik pengumpulan data, yaitu wawancara, observasi dan studi dokumen. Wawancara dilakukan kepada kepala, perwakilan guru, perwakilan siswa dan perwakilan orang tua siswa SD Kanisius Gendongan Salatiga untuk mencari data tentang pelaksaanaan, faktor yang mempengaruhi dan dampak dari program pendidikan karakter. Observasi dilakukan pada beberapa aspek sekolah meliputi: sarana dan prasarana sekolah, keterlibatan warga sekolah terhadap program pendidikan karakter dan strategi implementasi program pendidikan karakter di SD Kanisius Gendongan Salatiga. Observasi dilakukan untuk memperoleh data yang menguatkan dari hasil wawancara. Studi dokumen dilakukan untuk mengetahui beberapa aspek pelaksanaan dan dampak dari program pendidikan karakter di SD Kanisius Gendongan Salatiga.

Teknik analisis data yang akan digunakan dalam penelitian ini adalah teknis analisis data kualitatif model Miles dan Huberman yang meliputi: 1) pengumpulan data, 2) reduksi data, 3) penyajian data, 4) kesimpulan (Sugiyono, 2017:133-142). Pengumpulan data, kegiatan utama dalam pengumpulan data adalah mengumpulkan data yang diperoleh dari wawancara, obeservasi dan dokumentasi. Reduksi data, mereduksi data berarti merangkum, memilih hal-hal yang pokok. Penyajian data, penyajian data dilakukan dengan bentuk uraian singkat, bagan atau hubungan antar kategori. Penyajian data berupa teks naratif. Kesimpulan, kesimpulan dalam penelitian kualitatif dapat menjawab rumusan masalah yang dirumuskan sejak awal, namun tidak menutup kemungkinan akan berkembang setelah penelitian berada di lapangan.

Cara untuk menguji keabsahan data adalah dengan melakukan uji validitas dan reliabilitas data. Data dinyatakan valid apabila tidak ada perbedaan antara yang dilaporkan peneliti dengan apa yang sesungguhnya terjadi pada obyek yang diteliti. Reliabilitas dalam penelitian kualitatif, berarti bahwa suatu realitas itu bersifat majemuk/ganda., dinamis/selalu berubah. Validitas dan reliabilitas penelitian kualitatif meliputi: 1) Uji krediabilitas, peneliti memilih melakukan triangulasi teknik dan triangulasi sumber untuk menguji krediabilitas. Triangulasi teknik adalah cara untuk mengecek data pada sumber yang sama dengan teknik yang berbeda, misalnya diperoleh data dengan hasil observasi kemudian dicek dengan wawancara dan studi dokumen. Triangulasi sumber merupakan cara mendapatkan data dengan teknik yang sama dengan sumber yang berbeda. 2) Uji depenability, uji depenability dilakukan dengan melakukan audit terhadap keseluruhan proses penelitian yang dilakukan oleh auditor atau pembimbing untuk mengaudit keseluruhan aktivitas penelitian. 3) Uji konfirmability, uji konfirmability dalam penelitian 


\section{Jurnal Riset Pendidikan Dasar, 03 (1), April 2020 (77-86)}

Betles Natalini, Agustina Tyas Asri Hardini

kualitatif disebut dengan uji obyektivitas penelitian. Penelitian dikatakan obyektif apabila hasil penelitian merupakan fungsi dari proses penelitian yang dilakukan. 4) Uji transferability, uji transferability merupakan validitas eksternal. Validitas eksternal menunjukkan derajat ketepatan atau dapat diterapkannya hasil penelitian ke populasi dimana sampel tersebut diambil. Hasil penelitian dinyatakan memenuhi strandar transferbilitas apabila memperoleh gambaran "semacam apa" suatu hasil penelitian dapat diberlakukan (Sugiyono, 2017 :184-195).

\section{HASIL DAN PEMBAHASAN}

\section{Implementasi Program Pendidikan Karakter}

SD Kanisius Gendongan Salatiga adalah salah satu lembaga pendidikan yang berdiri dibawah Yayasan Kanisius. Berdasarkan data yang telah diperoleh dapat disimpulkan bahwa SD tersebut sudah mengimplentasikan program pendidikan karakter sejak lama, hanya saja untuk lima nilai pendidikan karakter yang diutamakan di sekolah yaitu kasih, disiplin, berani, jujur dan cerdas mulai disosialisasikan sekitar tahun 2012. Latar belakang dari adanya program pendidikan karakter di SD Kanisius Gendongan Salatiga adalah pembentukkan karakter merupakan hal yang utama dari proses pendidikan, apabila karakter peserta didik sudah terbentuk dengan baik maka prestasi ademik akan mampu mengikuti. Latar belakang adanya program pendidikan karakter di SD tersebut sesuai dengan tujuan adanya pendidikan karakter menurut Mulyasa (2011:9) pendidikan karakter bertujuan untuk meningkatkan mutu proses dan hasil pendidikan yang mengarah pada pembentukan karakter secara utuh, terpadu dan seimbang.

SD Kanisius Gendongan Salatiga dalam mengimplementasikan program pendidikan karakter memiliki pedoman visi dan misi sekolah seperti yang diungkapkan oleh beberapa narasumber ketika dilakukan wawancara. Sesuai dengan hasil dari observasi dan studi dokumen, visi dari SD Kanisius Gendongan Salatiga berisi unggul dalam pelayanan berkarakter dan nasionalis berdasarkan iman dan kasih menuju sekolah yang berkualitas. Sedangkan misi sekolah ini terdiri dari lima hal yang meliputi: 1) meningkatkan kecerdasan melalui proses pembelajaran aktif, kreatif, inovatif, dan menyenangkan, 2) menumbuhkan budi pekerti luhur, memiliki semangat nasionalisme, berkarakter berdasarkan semangat kasih, 3) menanamkan sikap disiplin melalui pembiasaan hidup tertib dan bertanggung jawab, 4) menanamkan kejujuran melalui pembiasaan berkomitmen, dapat dipercaya dan diandalkan, 5) menanamkan keberanian melalui pembiasaan kritis, reflektif dan aksi. Sesuai dengan pedoman pelaksanaan program pendidikan karakter di SD Kanisius Gendongan Salatiga dapat disimpulkan bahwa SD Kanisisus Gendongan Salatiga menjalankan fungsi pendidikan karakter menurut Sutjipto (2010:507) yaitu: Pertama, pembentukkan dan pengembangan potensi, adanya pendidikan karakter berfungsi membentuk dan mengembangkan potensi peserta didik agar bepikiran, berhati dan berperilaku baik. Kedua, perbaikan dan penguatan, pendidikan karakter memiliki fungsi untuk memperbaiki dan memperkuat peran sekolah, keluarga dan masyarakat untuk ikut bertanggung jawab untuk mengembangkan pembangunan bangsa. Ketiga, penyaring, pendidikan karakter berfungsi menyaring budaya sendiri dan menyaring budaya lain yang tidak sesuai dengan nilai-nilai dan karakter bangsa.

Kepala sekolah dan guru dalam mengimplementasikan program pendidikan karakter juga sudah mampu menjadi motivator dan teladan yang baik bagi peserta didik. Sesuai dengan peran pendidik bahwa guru tidak hanya mampu menjadi pendidik akademik, namun juga mendidik karakter peserta didik dengan beperan sebagai seorang model sekaligus mentor dan motivator yang meliputi olah pikir, hati dan rasa (Wardani, 2010:237). Kepala sekolah maupun guru melakukan pembinaan kepada peserta didik SD Kanisius Gendongan Salatiga. Setiap guru tidak hanya mampu mempraktikkan nilai-nilai yang baik kepada peserta didik namun juga kepada sesama guru. Hal ini sesuai dengan hasil obsevasi yang dilakukan oleh peneliti ditemukan Copyright (C2020, JRPD, ISSN 2615 - 1723 (Print), ISSN 2615 - 1766 (Online) 
adanya pembinaan tentang penerapan nilai-nilai yang baik dalam kehidupan sehari-hari ketika upacara berlangsung dan ketika apel pagi setiap hari Jumat. Aksi saling peduli antar kepala sekolah dan guru untuk menerapkan nilai-nilai yang baik kepada peserta didik juga terlihat dalam kehidupan sehari-hari.

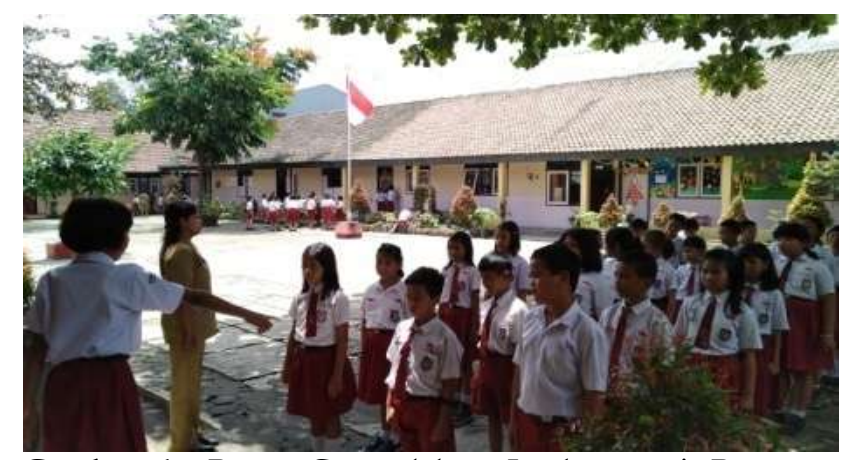

Gambar 1. Peran Guru dalam Implementasi Program Pendidikan Karakter

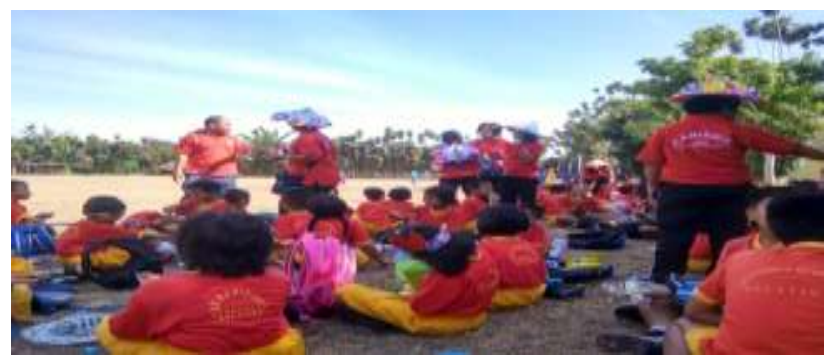

Gambar 2. Peran Kepala Sekolah dan Guru dalam aksi peduli untuk menerapkan nilai- nilai

Adanya program pendidikan karakter di SD Kanisius Gendongan Salatiga menimbulkan berbagai tanggapan dari orang tua dan peserta didik. Tanggapan orang tua dengan adanya program pendidikan karakter sangat mendukung, karena menurut sebagian orang tua yang terpenting dari pendidikan dasar adalah pembentukkan karakter bagi peserta didik. Sedangkan tanggapan dari peserta didik terhadap program pendidikan karakter di SD Kanisius Gendongan Salatiga sendiri tidak begitu mudah dalam mengimplementasikan karakter-karakter yang positif, mengingat dalam membentuk karakter yang baik memerlukan proses yang tidak sebentar dan perlu adanya pembiasaan. Seperti yang diungkapkan oleh Ainiyah (2013:28) bahwa pendidikan karakter merupakan pembelajaran yang teraplikasi ke seluruh kegiatan peserta didik melalui proses pembiasaan yang dilakukan secara berkesinambungan.

Strategi implementasi program pendidikan karakter yang ada di SD Kanisius Gendongan Salatiga sesuai dengan 6 (enam) langkah dalam mengimplementasikan program pendidikan karakter menurut Kemendiknas (2011:14-15) yang meliputi : 1) sosialisasi, SD Kanisius Gendongan Salatiga merupakan sekolah yang cukup aktif mensosialisasikan program pendidikan karakter selain ketika pembinaan upacara dan apel pagi kepada seluruh peserta didik. Kepala sekolah dan guru secara bergantian memberi pembinaan, menyampaikan nilai - nilai karakter yang baik kepada peserta didik dengan sederhana dan mudah diaplikasikan dalam kehidupan sehari-hari. Selain itu SD Kanisius Gendongan Salatiga juga melakukan sosialisasi kepada orang tua peserta didik pada saat pembagian raport dan adanya pertemuan orang tua siswa yang biasa disebut parenting. Kepala sekolah dan guru menyampaikan adanya nilai nilai dan tata tertib yang ada. 2) Pengembangan dalam kegiatan sekolah, pengembangan program pendidikan karakter juga ada dalam kegiatan sekolah pada acara keagamaan dan kegiatan di masa jeda semester, diantaranya outbond, makan bersama, beraneka macam perlombaan. Dari masing-masing kegiatan sekolah menerapkan nilai-nilai yang berbeda bergantung pada tema kegiatan yang dilaksanakan, nilai - nilai yang diterapkan pada setiap kegiatan berdasarkan nilai - nilai yang ada di SD Kanisius Gendongan Salatiga yaitu nilai kasih, jujur, berani, cerdas dan disiplin. 3) Pengembangan dalam kegiatan pembelajaran, pengembangan program pendidikan karakter juga ada pada kegiatan pembelajaran di masing-masing kelas. Setiap guru kelas mengimplementasikan secara langsung nilai-nilai karakter yang tercantum pada RPP, selain yang terdapat pada RPP guru kelas juga mengembangkan penerapan nilai - nilai sesuai dengan kondisi kelas dan kebutuhan peserta didik. Guru kelas juga memiliki buku penilaian sikap bagi setiap peserta didik. Guru kelas sesekali menegur peserta didik yang belum mampu 


\section{Jurnal Riset Pendidikan Dasar, 03 (1), April 2020 (77-86)}

Betles Natalini, Agustina Tyas Asri Hardini

menerapkan nilai - nilai karakter yang baik atau melanggar tata tertib. 4) Pengembangan budaya sekolah dan pusat kegiatan belajar, pengembangan program pendidikan karakter dalam budaya sekolah diantaranya pembiasaan senyum, salam, dan sapa, doa dan pembacaan renungan, menjaga kebersihan diri dan lingkungan dan Jumat Kasih (kegiatan memberi persembahan berupa uang setiap hari Jumat). 5) Adanya kegiatan ko kurikuler dan ekstrakurikuler, pengembangan program pendidikan karakter juga terdapat pada kegiatan ko kurikuler dan ekstrakurikuler. Kegiatan ko kurikuler yang dilakukan oleh guru SD Kanisius Gendongan Salatiga berupa pemberian tugas kelompok maupun individu sesuai dengan tingkat perkembangan dan kebutuhan peserta didik. Kegiatan ekstrakurikuler yang ada di SD Kanisius Gendongan Salatiga diantaranya pramuka sebagai ekrakurikuler wajib, taekwondo, drumband, dan tari. Masing-masing dari guru ekstrakurikuler memiliki kebebasan untuk mengembangkan setiap nilai-nilai karakter. 6) Kegiatan keseharian di rumah dan di masyarakat, dalam keseharian peserta didik sudah mampu menanamkan nilai nilai dibantu dengan pengawasan orang tua.

\section{Faktor yang Mempengaruhi Program Pendidikan Karakter}

Menurut Suparno (2018:71-73) terdapat beberapa faktor yang mempengaruhi implementasi program pendidikan karakter, yaitu : 1) lingkungan belajar, 2) lingkungan sosial, 3) pola asuh orang tua, dan 4) konsep diri peserta didik. Implementasi program pendidikan karakter di SD Kanisius Gendongan Salatiga dipengaruhi oleh ke empat faktor tersebut. Berdasarkan hasil wawancara dan observasi, maka diperoleh hasil sebagai berikut :

Pertama, lingkungan belajar, SD Kanisius Gendongan Salatiga memiliki lingkungan belajar yang nyaman, menyenangkan, dan aman. Hasil observasi yang ditemukan peneliti untuk mendukung implementasi program pendidikan karakter diantaranya : 1) slogan - slogan nilai Kanisius (Kasih, cerdas, disiplin, berani, jujur) yang ada di setiap kelas, dan di lingkungan sekolah. Dengan adanya slogan - slogan yang menarik diharapkan siswa akan mudah untuk menghafal, memahami, kemudian menerapkannya dalam kehidupan sehari - hari,

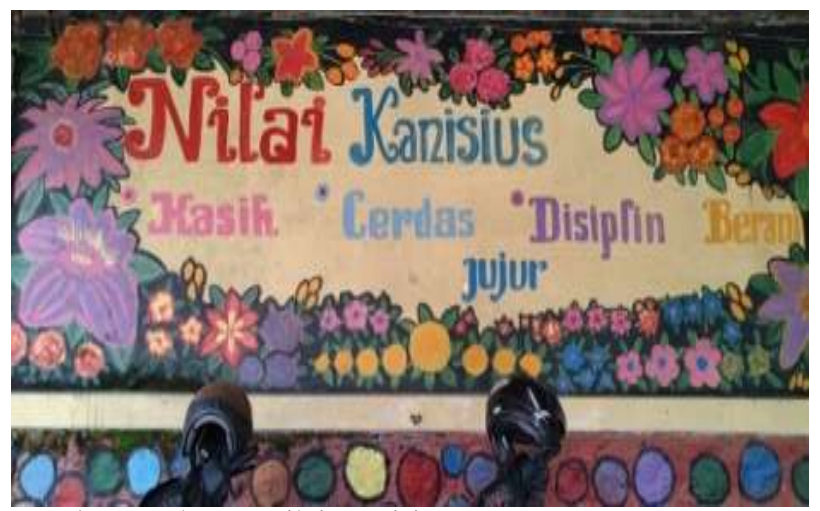

Gambar 3. Slogan Nilai Kanisius

2) alat-alat kebesihan yang ada di setiap kelas dan lingkungan sekolah diharapkan mampu membuat setiap peserta didik terbiasa menjaga kebersihan diri dan lingkungan,

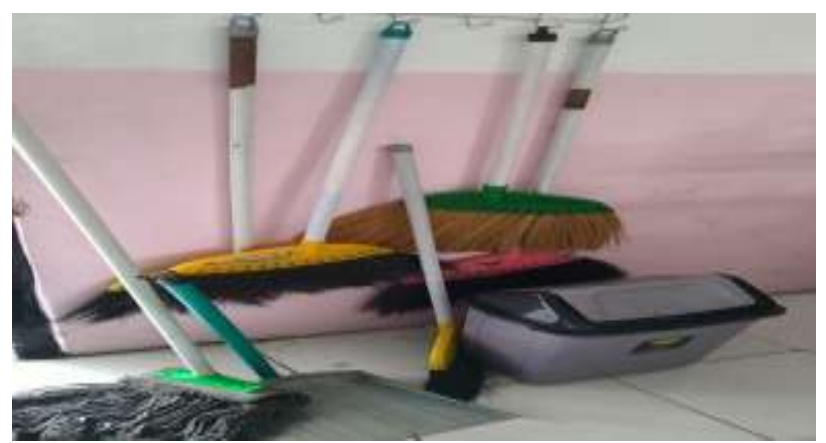

Gambar 4. Alat kebersihan

3) buku-buku cerita yang ada di setiap kelas dan perpustakaan. Buku cerita yang menarik minat peserta didik untuk membaca diharapkan mampu menjadi sumber belajar peserta didik dalam menerapkan nilai - nilai,

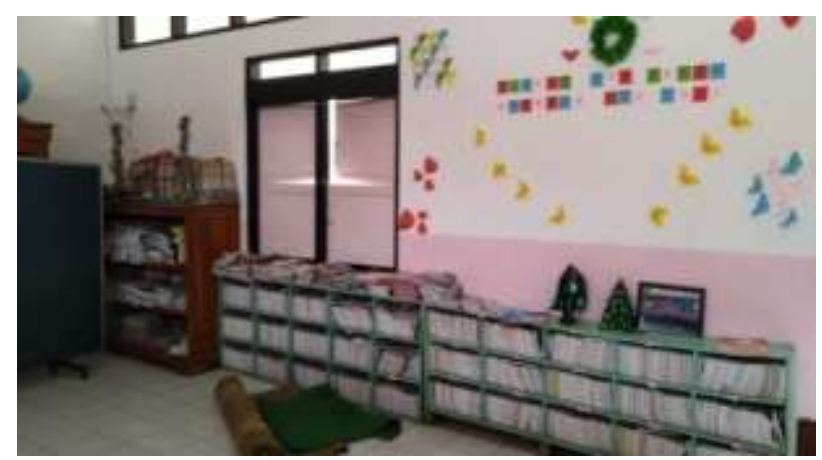

Gambar 5. Buku-buku bacaan

$$
\text { Copyright } \text { C2020, JRPD, ISSN } 2615 \text { - } 1723 \text { (Print), ISSN } 2615 \text { - } 1766 \text { (Online) }
$$




\section{Jurnal Riset Pendidikan Dasar, 03 (1), April 2020 (77-86)}

Betles Natalini, Agustina Tyas Asri Hardini

4) koperasi kejujuran yang ada di ruang tunggu kantor. Koperasi kejujuran yang ada di SD Kanisius Gendongan Salatiga menyediakan kebutuhan alat tulis bagi peserta didik. Setiap peserta didik secara mandiri, jujur dan bertanggung jawab memanfaaatkan sarana koperasi kejujuran tersebut.

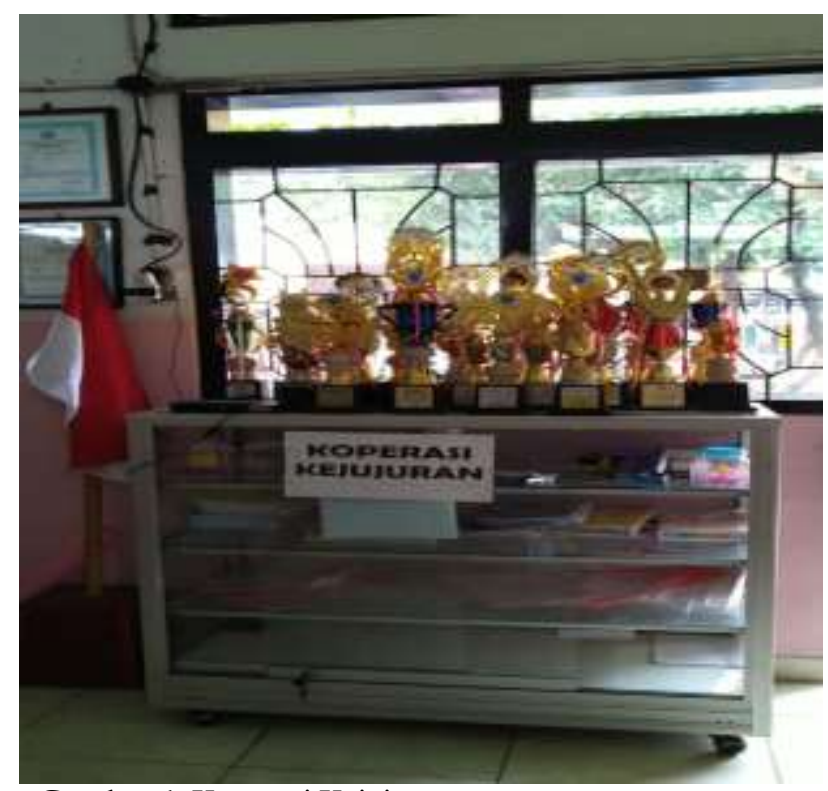

Gambar 6. Koperasi Kejujuran

Selain itu peran dari warga sekolah yang ikut mendukung terlaksananya program pendidikan karakter, warga sekolah yang dimaksud adalah kepala sekolah, guru, karyawan, dan setiap peserta didik. Berdasarkan hasil wawancara setiap peserta didik diajari untuk menjadi tutor sebaya tidak hanya dalam bidang akademik namun juga dalam menanamkan nilai nilai, setiap peserta didik diajarkan untuk membimbing dan menasehati teman yang lain. Selain kepala sekolah dan guru, teman sebaya ikut berperan dalam pembentukkan karakter peserta didik. Kurniawan dan Sudrajat (2017:7) menyatakan bahwa teman berperan sebagai agen sosialisasi yang berpengaruh, tercermin dari kebiasaan untuk saling mengingatkan tentang aturan sekolah yang berlaku.

Kedua, keadaan sosial, sebagian besar peserta didik memiliki keadaan lingkungan sosial yang mendukung implementasi program pendidikan karakter. Setiap orang tua peserta didik juga ikut berpartisipasi dalam mengamati lingkungan sosial peserta didik terutama teman sepermainan dari peserta didik. Teman sepermainan peserta didik juga memiliki peran sebagai model dalam bertingkah laku dan menerapkan kebiasaan.

Ketiga, pola asuh orang tua, pola asuh orang tua SD Kanisius Salatiga juga mendukung terbentukya karakter yang positif bagi setiap putra dan putrinya. Orang tua menyadari pentingnya untuk menanamkan nilai - nilai karakter yang positif bagi setiap anaknya, selain melakukan pengawasan, memberi nasehat, orang tua peserta didik juga terus berusaha menjadi teladan dalam menanamkan setiap nilai - nilai karakter.

Keempat, konsep diri, Berdasarkan hasil wawancara konsep diri yang berarti gambaran atau persepsi tentang peserta didik dalam implementasi program pendidikan karakter mendapat hasil bahwa sebagian dari peserta didik yang masih kesulitan untuk menerapkan nilainilai karakter dalam kehidupan sehari-hari.

\section{Dampak Implementasi Program Pendidikan Karakter}

SD Kanisius Gendongan Salatiga memiliki nilai-nilai karakter tertentu yang diutamakan dalam implementasi program pendidikan karakter diantaranya nilai kasih, jujur, disipin, berani, dan cerdas yang biasa disebut Nilai Kanisius. SD Kanisius Gendongan Salatiga menjadikan dasar nilai - nilai tersebut untuk mengembangkan nilai-nilai karakter yang lain seperti: 1) religius, 2) jujur, 3) toleransi, 4) disiplin, 5) kerja keras, 6) kreatif, 7) mandiri, 8) demokratis, 9) rasa ingin tahu, 10) semangat kebangsaan, 11) cinta tanah air, 12) menghargai prestasi, 13) bersahabat/komunikatif, 14) cinta damai, 15) gemar membaca, 16) peduli lingkungan, 17) peduli sosial, 18) tanggung jawab (Kurniawan 2013:41). Setiap nilai - nilai yang ditanamakan di SD Kanisius Gendongan Salatiga membawa dampak yang baik.

Adanya beberapa strategi yang diimplementasikan untuk menanamkan nilai nilai karakter, seperti adanya sosialisasi dan pengembangan program pendidikan karakter dalam kegiatan sekolah, kegiatan pembelajaran,

$$
\text { Copyright } \text { C2020, JRPD, ISSN } 2615 \text { - } 1723 \text { (Print), ISSN } 2615 \text { - } 1766 \text { (Online) }
$$




\section{Jurnal Riset Pendidikan Dasar, 03 (1), April 2020 (77-86)}

Betles Natalini, Agustina Tyas Asri Hardini

kegiatan ekstrakurikuler dan budaya sekolah membawa dampak bagi setiap peserta didik. Sosialisasi tentang pendidikan karakter berdampak memberi pemahaman tentang pentingnya menanamkan karakter yang baik sejak dini kepada peserta didik. Pengembangan berbagai kegiatan yang ada sekolah terhadap implementasi program pendidikan karakter membawa dampak bagi peserta didik untuk terbiasa menanamkan nilai Kanisus sebagai dasar berperilaku. Selain hal tersebut adanya faktor yang mendukung implementasi program pendidikan karakter, seperti keadaan lingkungan belajar, lingkungan sosial, dan pola asuh orang tua berdampak pada perilaku peserta didik dalam kehidupan sehari - hari, karakter - karakter yang baik mulai tertanam dan dalam diri sebagian besar peserta didik. Program pendidikan karakter berdampak positif bagi peserta didik dan dapat mengubah perilaku peserta didik yang kurang baik menjadi lebih baik (Khotimah dkk, 2019:160) Selain perubahan karakter juga terdapat juga pengaruh pendidikan karakter terhadap hasil belajar siswa secara akademik. Rijal dan Bachtiar (2015:16) menyimpulkan bahwa terdapat hubungan antara perilaku peserta didik dengan hasil belajar peserta didik, meskipun perilaku bukanlah satu-satunya penentu keberhasilan nilai akademik peserta didik. Pada umumnya peserta didik SD Kanisius Gendongan Salatiga dengan karakter yang baik akan lebih berpotensi untuk mendapat nilai akademik yang baik. Hal ini dikarenakan peserta didik yang sudah berhasil menanamkan nilai - nilai akan lebih mudah untuk diarahkan sehingga daya tangkap peserta didik terhadap pengetahuan akan lebih besar.

\section{SIMPULAN}

Berdasarkan hasil penelitian evaluasi implentasi program pendidikan karakter di SD Kanisius Gendongan Salatiga, dapat ditarik kesimpulan bahwa SD Kanisius Gendongan Salatiga dalam implementasi program pendidikan karakter mengembangkan beberapa strategi seperti adanya sosialisasi, pengembangan pendidikan karakter dalam kegiatan sekolah, kegiatan pembelajaran, kegiatan ekstrakurikuler dan budaya sekolah. Implementasi program pendidikan karakter didukung oleh beberapa faktor seperti keadaan lingkungan belajar, lingkungan sosial, dan pola asuh orang tua. Namun tanggapan dan konsep diri dari sebagian peserta didik SD Kanisius Gendongan Salatiga masih memerlukan pembiasaan untuk menanamkan setiap nilai-nilai karakter yang baik. Program pendidikan karakter sangat baik dan penting untuk terus diimplementasikan dan dikembangkan karena berdampak positif bagi pembentukkan karakter peserta didik dan hasil dari nilai akademik peserta didik.

Implementasi program pendidikan di SD Kanisius Gendongan Salatiga sudah berjalan dengan baik, hanya saja terdapat faktor penghambat dalam implementasi program pendidikan karakter yaitu tanggapan dan konsep diri dari peserta didik, dengan demikian peneliti memberi saran agar dalam implementasinya sekolah memberi reward kepada setiap peserta didik yang memiliki nilai sikap yang baik, sehingga setiap peserta didik memiliki tanggapan yang baik dengan adanya implementasi program pendidikan karakter.

\section{DAFTAR PUSTAKA}

Ainiyah, N. (2013). Pembentukkan Karakter melalui Pendidikan Agama Islam. AlUlum, 13(1), 25-38.

Arikunto, S., \& Jabar, C. A. (2014). Evaluasi Program Penididkan. Jakarta: Bumi Aksara.

Darmayanti, S. E., \& Wibowo, U. B. (2014). Evaluasi program pendidikan karakter di sekolah dasar Kabupaten Kulon Progo. Jurnal Prima Edukasia, 2(2), 223-234.

Jaelani, A., \& Asvio, N. (2019). Evaluasi Program Pendidikan Karakter di Sekolah Dasar. In Prosiding Seminar Nasional Program Pascasarjana Universitas PGRI Palembang.

Jahroh, W. S., \& Sutarna, N. (2016). PENDIDIKAN KARAKTER SEBAGAI UPAYA MENGATASIDEGRADASI MORAL. Prosiding Semiar Nasional Inovasi Pendidikan, 395-402.

$$
\text { Copyright } @ 2020 \text {, JRPD, ISSN } 2615 \text { - } 1723 \text { (Print), ISSN } 2615 \text { - } 1766 \text { (Online) }
$$




\section{Jurnal Riset Pendidikan Dasar, 03 (1), April 2020 (77-86)}

Betles Natalini, Agustina Tyas Asri Hardini

Kemendiknas. (2011). Panduan Pendidikan Karakter (berdasarkan pengalaman di satuan pendidikan rintisan). Jakarta: Kementerian Pendidikan Nasional Badan Penelitian dan Pengembangan Pusat Kurikulum dan Perbukuan.

Khotimah, D. N., Budiman, M. A., \& Subekti, E. E. (2019). Analisis Program Penguatan Pendidikan Karakter (PPK) di SDN Karanganyar Gunung 01 Semarang dan Dampaknya dalam Kehidupan Sehari-hari Siswa. In Seminar Pendidikan Nasional (Vol. 1, No. 1, pp. 157-162).

Kurniawan, S. (2013). Pendidikan Karakter : Konsepsi dan Implementasinya secara Terpadu di Lingkungan Keluarga, Sekolah, Perguruan Tinggi dan Masyarakat. Yogyakarta: Ar Ruzz Media.

Kurniawan, Y., \& Sudrajat, A. (2017). Peran Teman Sebaya dalam Pembentukkan Karakter Siswa MTs (Madrasah Tsanawiyah). SOCIAL: Jurnal Ilmu-ilmu Sosial.

Lickona, T. (2013). Educating for Character : Bagaimana Sekolah Dapat Mengajarkan Sikap Hormat dan Tanggung Jawab. Jakarta: Bumi Aksara.

Mulyasa, H. E. (2013). Manajemen Pendidikan Karakter. Jakarta: Bumi Aksara.

Muryadi, A. D. (2017). Model Evaluasi Program dalam Penelitian. Ilmiah PENJAS , 3, 1-16.

Rijal, S., \& Bachtiar, S. (2015). Hubungan antara Sikap, Kemandirian Belajar, dan Gaya Belajar dengan Hasil Belajar Kognitif Siswa. Jurnal Bioedukatika, 3(2), 15-20.

Saptono. (2011). Dimensi-dimensi Pendidikan Karakter. Salatiga: Erlangga.

Sugiyono. (2017). Metode Penelitian Kuantitatif, Kualitatif dan R\&D. Bandung: Alfabeta.

Sofanudin, A. (2015). Internalisasi Nilai-Nilai Karakter Bangsa Melalui Mata Pelajaran Pendidikan Agama Islam Pada SMA Eks-RSBI di Tegal. Jurnal SMART (Studi Masyarakat, Religi, dan Tradisi), 1(2).

Sukardi. (2014). Metodologi Penelitian Pendidikan Kompetensi dan Praktiknya. Jakarta: Bumi Aksara.

Suparno, S. (2018). Analisis Faktor-faktor Pembentuk Karakter Smart Siswa di Sekolah Islam Terpadu. Jurnal Pendidikan Karakter, 8(1), 62-73

Sutjipto. (2011). Rintisan Pengembangan Pendidikan Karakter di Satuan Pendidikan. Jurnal
Pendidikan dan Kebudayaan, 17(5), 501524

Syaikhudin, A. (2014). Evaluasi Pelaksanaan Pendidikan Karakter (Studi Kasus di Sekolah Dasar Ma'arif Ponorogo). TERAMPIL: Jurnal Pendidikan dan Pembelajaran Dasar, 1(1), 1-17.

Syamsani, S. (2019). Evaluasi Program Penguatan Pendidikan Karakter di SDN No. 39 Centre Palleko Kecamatan Polongbangkeng Utara Kabupaten Takalar (Doctoral dissertation, Universitas Negeri Makassar).

Taunu, E. S. H., \& Iriani, A. (2019). Evaluasi Program Penguatan Pendidikan Karakter Terintegrasi Mata Pelajaran Matematika di SMP Negeri. Kelola: Jurnal Manajemen Pendidikan, 6(1), 64-73.

Wardani,K. (2010). Peran Guru dalam Pendidikan Karakter Menurut Konsep Pendidikan Ki Hadjar Dewantara. In: Proceeding of The 4th International Conference on Teacher Education: Join Conference UPI\&UPSI(pp.8-10)

Wirawan. (2013). Kepemimpinan: Teori, Psikologi, Perilaku Organisasi, Aplikasi dan Penelitian. Jakarta: PT. Raja Grafindo Pustaka.

Copyright C2020, JRPD, ISSN 2615 - 1723 (Print), ISSN 2615 - 1766 (Online) 